\title{
Inhibitory Potentials of Hunteria umbellata Seed Extracts on Some Key Enzymes of Diabetes Mellitus with Profiling of its Phenolic Constituents
}

\author{
Habeeb A. Bankole*, Mutiu I. Kazeem, Monsurah A. Maliki, Samson S. Asokere, \\ Amaka C. Onyekwere
}

Department of Biochemistry, Faculty of Science, Lagos State University, Lagos, Nigeria

\author{
*Correspondence should be addressed to Habeeb A. Bankole: habeeb.bankole@lasu.edu.ng \\ Received 20th January 2021; Revised 5th March 2021; Accepted 19th March 2021 \\ (C) 2021 Bankole et al. Licensee Pan African Journal of Life Sciences an official publication of Faculty of Basic Medical Sci- \\ ences, Ladoke Akintola University of Technology, Ogbomoso. This is an Open Access article distributed under the terms of \\ the Creative commons Attribution License (https://creativecommons.org/licenses/BY/4.0), which permits unrestricted use, \\ distribution, and reproduction in any medium, provided the original work is properly cited.
}

\begin{abstract}
Background: The seeds of Hunteria umbellata is a common folkloric plant used in the management of Diabetes mellitus in Nigeria. Though there are many reports on its antidiabetic potential, there is a scarcity of information on its mechanisms of antidiabetic action. This study was designed to investigate the mechanism of antidiabetic action of $H$. umbellata seed by evaluating the inhibitory effect of its extracts on enzymes that are targeted in the management of diabetes mellitus.

Methods: Dried seeds of $H$. umbellata were powdered and extracted separately in water and ethanol. Alpha-amylase, $\alpha$-glucosidase, and sorbitol dehydrogenase inhibitory activities of the concentrated extracts were determined spectrophotometrically. Furthermore, the phenolic profile of the seed was determined using HPLC-UV analysis.

Results: The inhibitory effect of both ethanol and aqueous extracts $H$. umbellata on the selected enzymes were similar with IC50 value of $40.36 \pm 2.92$ and $40.25 \pm 4.53 \mathrm{mg} / \mathrm{mL}$ for $\alpha$-amylase, $45.42 \pm$ 2.44 and $39.32 \pm 3.46 \mathrm{mg} / \mathrm{mL}$ for $\alpha$-glucosidase, and $36.25 \pm 2.31$ and $32.35 \pm 1.53 \mathrm{mg} / \mathrm{mL}$ for sorbitol dehydrogenase, respectively. Kinetic studies showed that $\alpha$-amylase was inhibited competitively, while both $\alpha$-glucosidase and sorbitol dehydrogenase were inhibited in a non-competitive manner. The phenolic compounds identified in the $H$. umbellata seed were gallic acid, catechin, p-coumaric acid, rutin, and ferulic acid.

Conclusion: The H. umbellata seed extract's antidiabetic action may be by inhibiting the activities of $\alpha$-amylase, $\alpha$-glucosidase, and sorbitol dehydrogenase. This inhibition could be due to the presence of phytochemicals such as phenolic compounds in the plant.
\end{abstract}

Keywords: Hunteria umbellata, Diabetes, $\alpha$-amylase, $\alpha$-glucosidase, Sorbitol dehydrogenase 


\section{INTRODUCTION}

Diabetes mellitus is one of the widespread noncommunicable diseases globally. It accounts for about eight million deaths annually from an estimated 173 million adult diabetics worldwide [1]. Non-insulindependent diabetes mellitus (NIDDM) or type 2 diabetes mellitus is the most prevalent and accounts for about $90 \%$ of all diabetes cases [2]. It is due to either the pancreas not producing enough insulin or the body's cells not responding correctly to the insulin produced [3]. Increased blood glucose concentration, termed hyperglycemia, is linked to the onset of type 2 diabetes mellitus, which is associated with several complications including hypertension, retinopathy, and nephropathy[4].

Prevention and treatment of diabetes mellitus involve regulating blood glucose levels in people with diabetes or those with high risk. It also involves consuming healthy diets, doing regular physical exercise, and maintaining normal body weight [5]. Insulin and some oral hypoglycemic medications can reduce blood glucose levels [6], while weight loss surgery for those who are obese is sometimes an effective measure for treating type2 Diabetes mellitus [7]. Despite the appreciable progress made in the management of diabetes using conventional drugs and management strategies, diabetes and its complications continue to be a significant medical problem. Most synthetic oral hypoglycaemic agents recommended for managing this disease have some limitations that include serious side effects, inaccessibility to specialists and drugs, high cost, and rigid treatment regimen $[8,9]$.

In addressing the limitations encountered in the management of diabetes mellitus using synthetic drugs, the WHO expert committee on diabetes mellitus recommended further analysis of folkloric herbs and methods used in the management of diabetes mellitus [10]. Also, many people are turning to traditional herbal medicines to prevent and treat diabetes throughout the world due to easy accessibility and perceived safety [11, 12]. Some of these herbs commonly used in Africa traditional medicine in the management of diabetes mellitus are based on claims of having healing properties against many ailments [13]. One of such indigenous herbs used in the management of diabetes mellitus among the Yoruba tribe of South-West Nigeria is Hunteria umbellata known locally as 'Abeere' [14].

Hunteria umbellata K. Schum (family: Apocynaceae) is a small glabrous tree with a dense crown, native to the tropic of West Africa. The yellow, smooth fruits carry seeds, which are enclosed in the pulp. The seeds, root, bark, and leaves are highly valued for their medicinal properties [14]. It is called 'abeere' or 'arin' in Yoruba, 'osu' in Edo, and 'nkpokiri' in Igbo [15]. In African folk medicine, the plant has wide therapeutic uses, including treatment of pains, gastric ulcers, liver diseases, obesity, diabetes mellitus, pregnancy-related ailments, and to induce or augment labour at term, among many other uses[16]. The dried seeds are popularly used to treat diabetes in Nigeria, with claims of having the ability to lower blood sugar levels [17]. Also, several scientific reports have confirmed the hypoglycemic effect of the extracts of this dried seed using different diabetes models in animals [14, 17].

The seed's phytochemical constituents revealed the presence of alkaloids, flavonoids, tannins, and glycosides, and the hypoglycemic effects of the aqueous seed extract of $H$. umbellata in nicotine-induced hyperglycemic rats showed a dose-related reduction in the blood glucose levels [14]. The boiled extract was reported to reduce blood glucose levels and increase liver glycogen levels in streptozotocin-induced diabetes rats [17]. Diabetic patients placed on a twice-a-day dose of the $H$. umbellata treatment with metformin attained normal glucose level in three weeks, compared to eight weeks with patients treated only with metformin [16]. However, despite the local claims of efficacy of the plant decoction in managing diabetic patients, the scientific studies have majorly focused on the blood glucose reducing property of the seed extract without providing the mechanism(s) behind the hypoglycemic activity of the plant.

Therefore, this study evaluated the inhibitory effect of the $H$. umbellata seed extract on some enzymes targeted in the management of diabetes mellitus, as a probable mechanism of action for its hypoglycemic property.

\subsection{MATERIALS AND METHOD}

\subsection{Plant Material}

Hunteria umbellata seeds were purchased from a local market at Agbalata in Badagry, Lagos State, Nigeria. The sample was authenticated at the Department of Botany, Faculty of Science, University of Lagos, Akoka, Lagos, where a voucher specimen number LUH 8377 was assigned and deposited at the university herbarium. Samples were then dried under shade, blended into fine pow- 
der form, and stored in a dried container before use.

\subsection{Chemicals}

The $\alpha$-amylase from Aspergillus oryzae, $\alpha$-glucosidase from Saccharomyces cerevisiae, D-sorbitol, NADH, sorbitol dehydrogenase, tris buffer, acarbose, quercetin, maltose, and soluble starch (extra pure) were products of Sigma-Aldrich Co., St Louis, USA. Other chemicals and reagents used were of analytical grade while the water used was glass distilled.

\subsection{Preparation of Plant Extracts}

The powdered sample was divided into two portions of $10 \mathrm{~g}$ each, and these were extracted for $48 \mathrm{~h}$ in ethanol and distilled water, respectively. All extracts were filtered using Whatman No. 1 filter paper. The filtrates were further concentrated by leaving the ethanol extract open in a water bath at $40{ }^{\circ} \mathrm{C}$ for the ethanol to evaporate. The water extract was freeze-dried using a freeze dryer. Concentrated crude extracts were weighed and dissolved in $10 \%$ dimethyl sulfoxide (DMSO) to yield a stock solution of $1.0 \mathrm{mg} / \mathrm{mL}$ from which lower concentrations $(125,250$ and $500 \mu \mathrm{g} / \mathrm{mL})$ were prepared using distilled water.

\subsection{HPLC-Analysis of Polyphenolic Compounds}

The polyphenolic contents of the H. umbellate were determined using high-performance liquid chromatography (HPLC Argilent technology 1200 series) coupled with an automatic injector (Argilent technology 1100 series). Two gram of the sample was milled into fine form, and $10 \mathrm{ml}$ of a mixture (50:50) of acetonitrile and methanol was added to the fine sample for extraction. It was vortexed thoroughly for about $20 \mathrm{~min}$ and the organic layer produced was poured into a beaker. $10 \mathrm{~mL}$ of the mixture of acetonitrile and methanol was added again to get a clean mixture. It was then filtered using a filter paper and then clean-up by passing through a silica gel-packed column. The conditioned packed column was run with 10 $\mathrm{mL}$ of HPLC-grade methanol (conditioning). The extract was allowed to run through the column to remove unnecessary fragments, and the column was eluted with HPLCgrade methanol to remove any other particle present. The clean, clear extract was concentrated and reconstituted with $1 \mathrm{~mL}$ of methanol-acetonitrile mixture that was run on the column. UV-detector was used at $280 \mathrm{~nm}$ to monitor the detection of the analyte. An injection volume of about $10 \mu \mathrm{L}$ was injected into the machine. The flow rate was $0.8 \mathrm{~mL} / \mathrm{min}$, and the length of the column was $150 \times 4.6 \mathrm{~mm}$. The mobile phase was acidified water and acetonitrile.

\subsection{Determination of inhibitory activities of the con- centrated extracts}

i. The modified procedure of McCue \& Shetty [18] was used to evaluate the inhibition of $\alpha$-amylase by graded concentration $(125-1000 \mu \mathrm{g} / \mathrm{mL})$ of the extracts. Distilled water substituted the extracts in a control solution following the same procedure [19].

ii. The $\alpha$-glucosidase inhibitory activity was determined by the modified method described by Kim et al. [20] using varying concentrations $(125-1000 \mu \mathrm{g} / \mathrm{mL})$ of the extracts.

iii. Inhibition of sorbitol dehydrogenase activity by different concentrations $(125-1000 \mu \mathrm{g} / \mathrm{mL})$ of the extracts were evaluated using the modified procedure [21].

\subsection{Calculation of percentage inhibition of enzymes}

The percentages inhibition of the three enzymes $(\alpha-$ amylase, $\alpha$-glucosidase and sorbitol dehydrogenase) were determined using the equation:

$$
\% \text { Inhibition }=\left[\frac{\left(A b s_{\text {control- }} A b s_{\text {extract }}\right)}{A b s_{\text {control }}}\right] x 100
$$

Where $\mathrm{Abs}_{\text {control }}$ is the absorbance of control while Abs extract is the absorbance of extracts.

\subsection{Calculation of IC50 values of enzymes' inhibition}

The concentration of extract or standard that inhibited $50 \%$ of enzyme activities (IC50) was evaluated graphically by plotting percentage inhibition of enzymes against the concentration of extract using Microsoft Excel (2010).

\subsection{Determination of kinetics of inhibition of the en- zymes}

The modes of inhibition of the enzymes ( $\alpha$-amylase, $\alpha$ glucosidase, and sorbitol dehydrogenase) by the ethanol extract of H. umbellata were determined from a doublereciprocal plot using Michaelis Menten kinetics [22].

\subsection{Statistical analysis}

All results were expressed as mean \pm SEM of triplicate determinations. Data were analyzed using analysis of variance (ANOVA) followed by Bonferroni test ( $p<$ 0.05), with the aid of GraphPad Prism 5. 


\section{RESULTS}

\subsection{Inhibition of $\alpha$-amylase activity}

Figure 1 shows the level of inhibition of $\alpha$-amylase by aqueous and ethanol extracts of $H$. umbellata at varying concentrations $(125,250,500,1000 \mu \mathrm{g} / \mathrm{mL})$. Inhibition of the enzyme by both aqueous and ethanol extracts was dose-dependent and their level of inhibitions was similar $(p>0.05)$ at the lowest and highest concentrations. However, the percentages inhibition of the ethanol extract at 250 and $500 \mu \mathrm{g} / \mathrm{mL}$ were significantly higher $(\mathrm{p}<0.05)$ than aqueous extract.

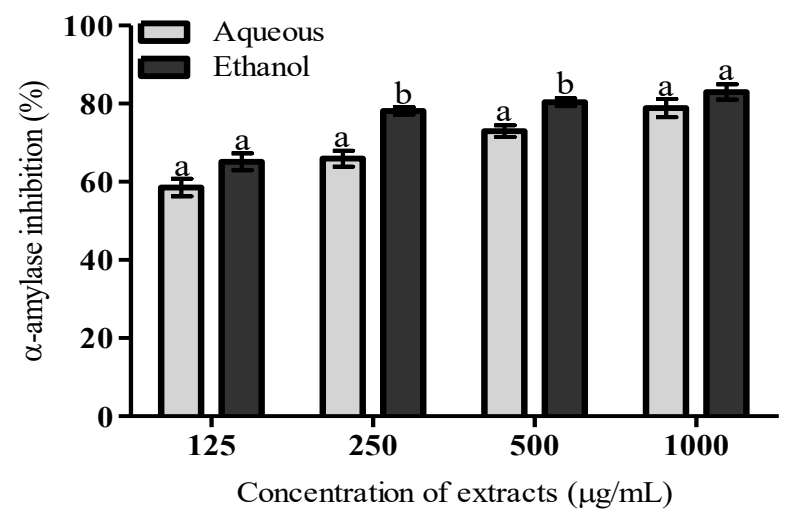

Figure 1. Inhibitory effects of aqueous and ethanol extracts of Hunteria umbellata on alpha-amylase activity. Values represent the mean \pm SEM of triplicate experiments. Bars with different superscripts at the same concentration are significantly different $(\mathrm{p}<.05)$.

\subsection{Inhibition of $\alpha$-glucosidase activity}

Figure 2 represents the level of inhibition of $\alpha$ glucosidase by both aqueous and ethanol extracts of Hunteria umbellata at varying concentrations $(125,250,500$, $1000 \mu \mathrm{g} / \mathrm{mL}$ ). The inhibitory effects of both extracts were dose-dependent, however, the level of inhibition by the ethanol extracts was significantly higher $(\mathrm{p}<0.05)$ at all concentrations compared to the aqueous extracts.

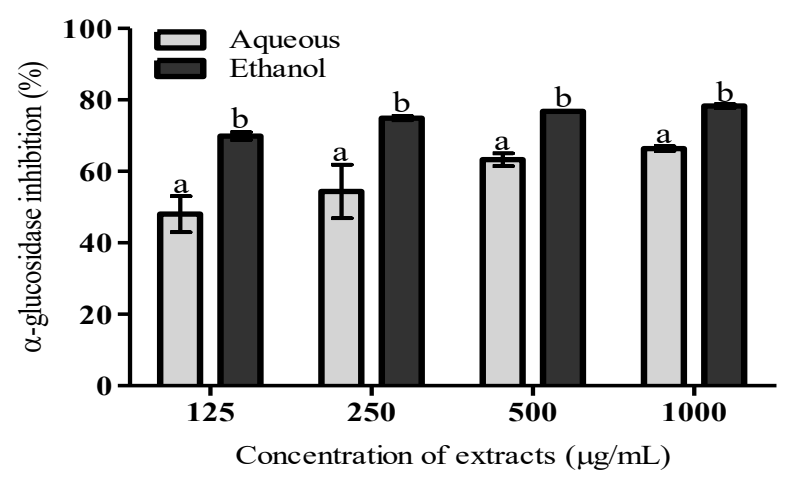

Figure 2. Inhibitory effects of aqueous and ethanol extracts of Hunteria umbellata on alpha-glucosidase activity. Values represent the mean \pm SEM of triplicate experiments. Bars with different superscripts at the same concentration are significantly different $(\mathrm{p}<0.05)$.

\subsection{Inhibition of sorbitol dehydrogenase activity}

Figure 3 represents the level of sorbitol dehydrogenase inhibition by ethanol and aqueous extracts of $H$. umbella$t a$. The extracts inhibited the enzyme in a dose-dependent manner. Although the figure shows the percentage inhibition of the ethanol extracts were higher than the aqueous extracts, the differences were not significantly different $(\mathrm{p}>0.05)$ at all concentrations tested.



Figure 3. Inhibitory effects of aqueous and ethanol extracts of Hunteria umbellata on sorbitol dehydrogenase activity. Values represent the mean \pm SEM of triplicate experiments. Bars with different superscripts at the same concentration are significantly different $(\mathrm{p}<$ $0.05)$.

\subsection{Inhibitory concentration at $50 \%$ enzyme activities}

The IC50 (extract concentration causing 50\% enzyme inhibition) values of the extract against $\alpha$-glucosidase, $\alpha$ amylase, and sorbitol dehydrogenase activity was determined (Table 1). There was no significant statistical difference in the IC50 values between the ethanol and aqueous extract against the three enzymes. However, the ethanol and aqueous extracts of $H$. umbellata had significantly lower IC50 compared to acarbose for $\alpha$-amylase and $\alpha$ glucosidase, as well as quercetin for sorbitol dehydrogenase activity.

Table 1. Inhibition concentration $\left(\mathrm{IC}_{50}\right)$ values of $\alpha$ Amylase, $\alpha$-Glucosidase, and sorbitol dehydrogenase by aqueous and ethanol extracts of Hunteria umbellata

\begin{tabular}{|l|l|l|l|}
\hline Samples & & $\mathrm{IC}_{50}$ values & \\
\hline & $\alpha$-amylase & $\begin{array}{l}\alpha \text { - } \\
\text { glucosidase }\end{array}$ & $\begin{array}{l}\text { Sorbitol de- } \\
\text { hydrogenase }\end{array}$ \\
\hline $\begin{array}{l}\text { Aqueous } \\
\text { extract }\end{array}$ & $40.36 \pm 2.92^{\mathrm{a}}$ & $45.42 \pm 2.44^{\mathrm{a}}$ & $36.25 \pm 2.31^{\mathrm{a}}$ \\
\hline $\begin{array}{l}\text { Ethanol } \\
\text { extract }\end{array}$ & $40.25 \pm 4.53^{\mathrm{a}}$ & $39.32 \pm 3.46^{\mathrm{a}}$ & $32.35 \pm 1.53^{\mathrm{a}}$ \\
\hline Acarbose & $67.5 \pm 4.62^{\mathrm{b}}$ & $104.61 \pm 1.23^{\mathrm{b}}$ & $\mathrm{ND}$ \\
\hline Quercetin & $\mathrm{ND}$ & $\mathrm{ND}$ & $67.50 \pm 0.83^{\mathrm{b}}$ \\
\hline
\end{tabular}

ND: Not Determined. Values presented are mean \pm SEM of experiments carried out in triplicate. Columns with different alphabetical superscripts are significantly $(\mathrm{p}<0.05)$ different. 


\subsection{Kinetics of inhibition of extracts}

Kinetic studies were performed to determine the enzymes' mode of inhibition by Lineweaver-Burk plot, using the most potent (extract with the lowest IC50) inhibitor. Figures 4, 5 and 6 showed the Double reciprocal plot of the modes by which ethanol extract of $\mathrm{H}$. umbellata inhibits $\alpha$-amylase, $\alpha$-glucosidase, and sorbitol dehydrogenase, respectively. The plots showed that $\alpha$-glucosidase and sorbitol dehydrogenase were inhibited in a noncompetitive manner, while the $\alpha$-amylase was inhibited competitively.

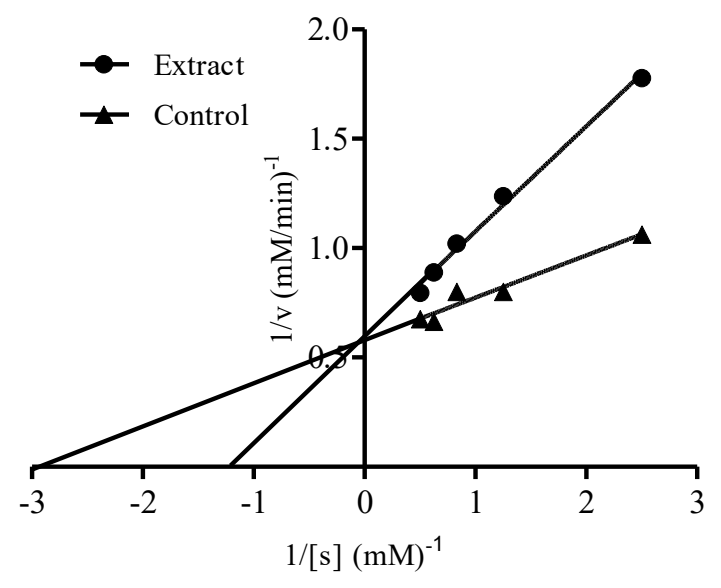

Figure 4. Mode of inhibition of $\alpha$-amylase by ethanol extract of Hunteria umbellata

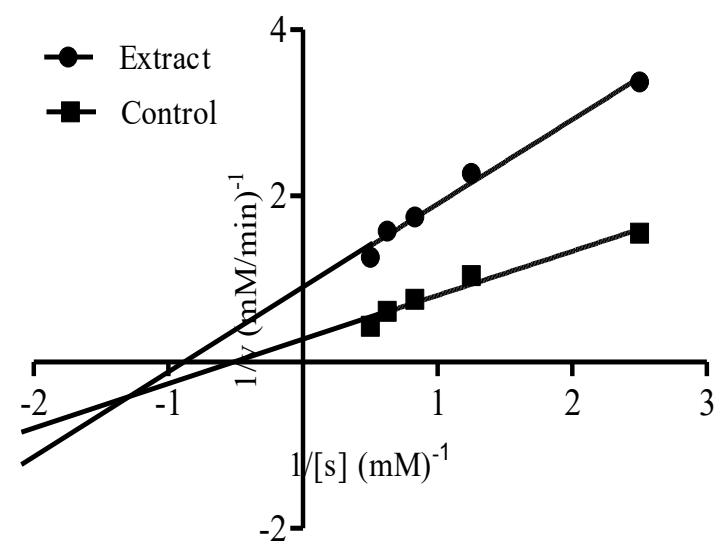

Figure 5. Mode of inhibition of $\alpha$-glucosidase by ethanol extract of Hunteria umbellata

\subsection{Polyphenolic composition}

Figure 7 shows the spectrum of polyphenols identified in the HPLC-UV analysis for aqueous extract of $\mathrm{H}$. umbellata at $280 \mathrm{~nm}$. Phenolic compounds present are gallic acid, catechin, p-coumaric acid, rutin, and ferulic acid as shown by peaks with retention times of $7.777 \mathrm{~min}$, $15.266 \mathrm{~min}, 18.474 \mathrm{~min} 20.247 \mathrm{~min}$, and $23.963 \mathrm{~min}$, respectively.

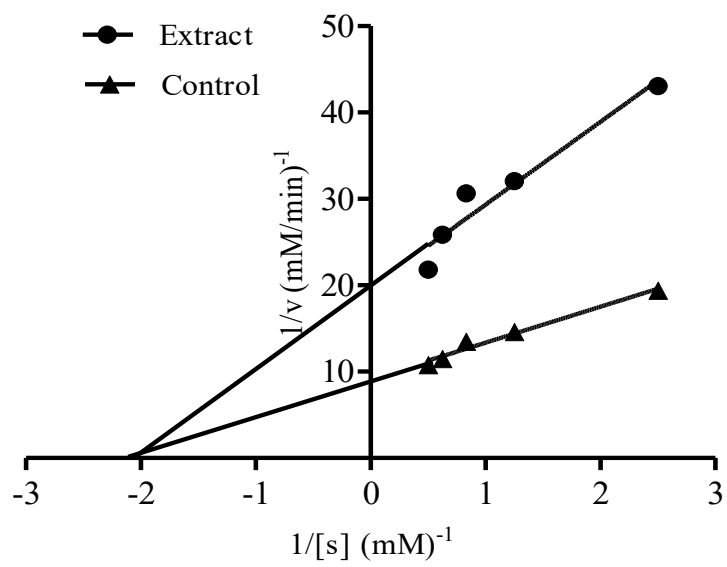

Figure 6. Mode of inhibition of sorbitol dehydrogenase by aqueous extract of Hunteria umbellata

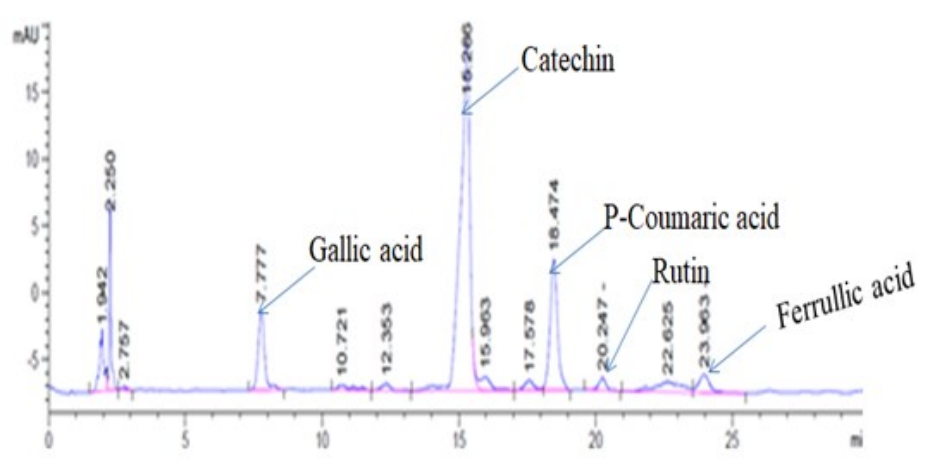

Figure 7. HPLC profile of aqueous extract of Hunteria umbellata at $280 \mathrm{~nm}$.

\section{Discussion}

One of the most effective approaches adopted in the management of diabetes mellitus, especially type- 2 diabetes, is to target the modulation of enzymes involved in carbohydrate metabolism, especially by inhibiting carbohydrate hydrolyzing enzymes in the gastrointestinal tract [23]. In recent times, more attention is focused on natural products that may be beneficial in the treatment of diabetes. Inhibitors of $\alpha$-amylase and $\alpha$-glucosidase are known to significantly decrease postprandial blood glucose levels after a high carbohydrate meal and are employed as an approach in managing diabetes [24]. However, an increase in blood glucose level could also be managed by inhibiting the two enzymes of the polyol pathway; aldose reductase and sorbitol dehydrogenase [25].

The polyol pathway is a glucose metabolism alternate route that is initiated in tissues that can take-up glucose without insulin assistance. The pathway involves converting glucose to sorbitol by aldose reductase and then sorbitol dehydrogenase, further metabolizing the sorbitol to fructose [26]. Elevation of fructose through sorbitol 
dehydrogenase activity may promote the production of advanced glycation end products, which contributes to complications in diabetes. Thus, agents that could inhibit the activity of enzymes of the polyol pathway are used to prevent or ameliorate diabetic complications [27].

This study compared the inhibitory effects of the aqueous and ethanol extracts of $\mathrm{H}$. umbellata seeds on the activities of $\alpha$-amylase, $\alpha$-glucosidase, and sorbitol dehydrogenase. The fact that both extracts' effects were dosedependent and levels of inhibition were similar indicates that the active inhibitory constituents of the seeds are soluble in both water and ethanol. The lower IC50 values of the extracts compared to the standard drugs suggest that the extracts could be more effective as inhibitors of $\alpha$ -amylase and $\alpha$-glucosidase than acarbose. This is also applicable to the inhibition of sorbitol dehydrogenase by the extracts. The lower the IC50 values, the better the inhibition of the enzymes [28].

The enzyme responsible for the breakdown of polysaccharides to simpler sugar in the human body is $\alpha$ amylase. Complex polysaccharides are hydrolyzed by this enzyme to produce oligosaccharides and disaccharides which are further broken down by $\alpha$-glucosidase to monosaccharides that are absorbed through the small intestine into the hepatic portal vein to increase the postprandial blood glucose levels [29]. Thus, inhibition of $\alpha$ amylase and $\alpha$-glucosidase will decrease postprandial glucose levels. H. umbellata seeds' Extracts demonstrated significant $\alpha$-amylase and $\alpha$-glucosidase inhibition, indicating their potential role as a probable antidiabetic agent. The mode of inhibition of $\alpha$-amylase and $\alpha$ glucosidase by the extracts was shown to be competitive and non-competitive inhibition, respectively. This suggests that the inhibitory compounds bind the active site of $\alpha$-amylase while the inhibitor does not compete for the active site in inhibiting $\alpha$-glucosidase. This result is similar to earlier studies that reported that the aqueous extract of $H$. umbellata inhibited $\alpha$-amylase activity $[30,31]$.

Chronic hyperglycemia resulting from diabetes is associated with long-term damage or dysfunction of various organs such as the eyes, kidneys, nerves, heart, and blood vessels [32]. The polyol pathway is one of the most effective mechanisms by which complications of diabetes occur since it is activated when the glucose level increased. The inhibition of sorbitol dehydrogenase activity by the extracts of $H$. umbellatta may mitigate the formation of advanced glycation end products, thereby contributing to the prevention and or palliation of diabetic complications [33]. The non-competitive inhibition of sorbitol dehydrogenase by the extract may suggest that the extract's inhibitory components do not contend with the substrate in binding to the enzyme's active site but rather interact with the enzyme at a separate site to inhibit the enzyme activity. The benefits of the noncompetitive inhibitors (such as drugs) is that they decrease the enzyme's turnover rate rather than prevent the substrate from binding the enzyme. Instead of the reaction of the enzyme being stopped, it is reduced and the reaction cannot be reversed by increasing the concentration of the substrates [34].

Phenolic compounds have attracted much attention due to their various biological activities, including enzyme inhibition and anti-diabetic activity [35]. Five individual phenolic compounds were identified from the H. umbellatta seed, which could contribute to the $\alpha$-amylase, $\alpha$ glucosidase, and sorbitol dehydrogenase inhibitory activities. Some of these compounds have been identified and isolated from extracts of the seeds of H. umbellatta [30, 31]. Gallic acid has been reported to attenuate insulin resistance in streptozotocin (STZ)-induced diabetic rats [36] while catechin ameliorates diabetes and its complications [37]. p-coumaric acid modulates glucose and lipid metabolism via pancreatic glucose transporter 2 activation [38], and ferulic acid protects against STZinduced diabetic nephropathy [39]. Rutin from tartary buckwheat possessed hypoglycemic property in type-2 diabetic mouse model [40]. Some of these phenolic compounds have also been reported to be responsible for the antidiabetic activity of plants by inhibiting the activities of enzymes targeted in the management of diabetes mellitus [35]. These are indications that the extracts of $H$. umbellatta seed possess antidiabetic properties partly due to their ability to inhibit diabetes-related enzymes.

This study demonstrated that both aqueous and ethanol extracts of $H$. umbellatta inhibit the activities of $\alpha$ amylase, $\alpha$-glucosidase, and sorbitol dehydrogenase. The ethanol extract competitively inhibited the activity of $\alpha$ amylase, while the activities of $\alpha$-glucosidase and sorbitol dehydrogenase were inhibited in a non-competitive manner. The inhibitory effect of the H. umbellatta seed extracts may be due to the presence of polyphenols (gallic acid, catechin, p-coumaric acid, rutin and ferulic acid. However, individual inhibitory effects of these identified polyphenols from $\mathrm{H}$. umbellatta seeds needs to be carried out to confirm their specific role in ameliorating diabetes mellitus. 


\section{Declaration of conflict of interest}

The Authors declare that there is no conflict of interest.

\section{Funding Statement}

This research was self-funded by the authors

\section{Authors Contribution}

HAA Conceived and designed the study, performed analysis and wrote the paper. MIL Conceived, designed and participated in analysis. MAM Collected data and wrote the paper. SSA and MCO Performed statistical analysis. All authors approved the final version of the manuscript.

\section{References}

1. Zheng Y, Ley SH, Hu FB. Global aetiology and epidemiology of type 2 diabetes mellitus and its complications. Nature Reviews Endocrinology 2018; 14(2): 88-98.

2. Chung MJ, Cho S-Y, Bhuiyan MJH, Kim KH, Lee S-J. Anti-diabetic effects of lemon balm (Melissa officinalis) essential oil on glucose-and lipid-regulating enzymes in type 2 diabetic mice. British Journal of Nutrition 2010; 104 (2): $180-188$.

3. Shoback D, Gardner D. Chapter 17. Greenspan's basic \& clinical endocrinology (9th ed) New York: McGraw-Hill Medical 2011: 217-236.

4. Chilelli N, Burlina S, Lapolla A. AGEs, rather than hyperglycemia, are responsible for microvascular complications in diabetes: a "glycoxidation-centric" point of view. Nutrition, Metabolism and Cardiovascular Diseases 2013; 23 (10): 913-919.

5. Boles A, Kandimalla R, Reddy PH. Dynamics of diabetes and obesity: epidemiological perspective. Biochimica et Biophysica Acta (BBA)-Molecular Basis of Disease 2017; 1863(5):.1026-1036.

6. Tao Z, Shi A, Zhao J. Epidemiological perspectives of diabetes. Cell Biochemistry and Biophysics 2015; 73(1): 181185.

7. Picot J, Jones J, Colquitt J, Gospodarevskaya E, Loveman E, Baxter L, Clegg A. The clinical effectiveness and costeffectiveness of bariatric (weight loss) surgery for obesity: a systematic review and economic evaluation. 2009; 13 (41): 1-230.

8. Adeneye A, Agbaje E. Pharmacological evaluation of oral hypoglycemic and antidiabetic effects of fresh leaves ethanol extract of Morinda lucida Benth. in normal and alloxan -induced diabetic rats. African Journal of Biomedical Research. 2008; 11(1): 65-71.

9. Kumari K, Suresh T, Samarasinghe K, Handunnetti S, Samaranayake T. Evaluation of a traditional Sri Lankan herb- al beverage (water extract of dried flowers of Aegle marmelos, Bael fruit) in type II diabetic patients. Journal of Diabetes \& Metabolism, 2013; (1): 4-6.

10. Yerima M, Anuka J, Salawu O, Abdu-Aguye I. Antihyperglycaemic activity of the stem-bark extract of Tamarindus indica L. on experimentally induced hyperglycaemic and normoglycaemic Wistar rats. Pakistan Journal of Biological Sciences 2014; 17(3): 414-418.

11. Shakya AK. Medicinal plants: future source of new drugs. International Journal of Herbal Medicine 2016; 4(4): 5964.

12. Broadhurst CL, Polansky MM, Anderson RA. Insulin-like biological activity of culinary and medicinal plant aqueous extracts in vitro. Journal of Agricultural and Food Chemistry 2000; 48(3): 849-852.

13. El-Tantawy WH, Temraz A. Management of diabetes using herbal extracts. Archives of physiology and biochemistry 2018; 124(5): 383-389.

14. Adeneye A, Adeyemi O. Hypoglycemic effects of the aqueous seed extract of Hunteria umbellata in normoglycemic and glucose and nicotine induced hyperglycemic rats. Planta Medica 2008; 74(09): PA245.DOI: 10.1055/s-00281084243

15. Sofowora A. Research on medicinal plants and traditional medicine in Africa; J Altern Complement Med Fall 1996;2 (3):365-72.. doi: 10.1089/acm.1996.2.365.

16. Ajibola O, Akinmegha T, Balogun O. Biometric Analysis of Hunteria umbellata (K. Schum.) Hallier $f$ and Metformin in the treatment of diabetes. Journal of Applied Sciences and Environmental Management 2018; 22(4): 561-564.

17. Igbe I, Omogbai EK, Ozolua RI. Hypoglycemic activity of aqueous seed extract of Hunteria umbellata in normal and streptozotocin-induced diabetic rats. Pharmaceutical Biology 2009; 47(10): 1011-1016.

18. McCue PP, Shetty K. Inhibitory effects of rosmarinic acid extracts on porcine pancreatic amylase in vitro. Asia Pacific Journal of Clinical Nutrition 2004; 13(1): 101-106.

19. Ali H, Houghton P, Soumyanath A. $\alpha$-Amylase inhibitory activity of some Malaysian plants used to treat diabetes; with particular reference to Phyllanthus amarus. Journal of ethnopharmacology 2006; 107(3): 449-455.

20. Kim Y-M, Jeong Y-K, Wang M-H, Lee W-Y, Rhee H-I. Inhibitory effect of pine extract on $\alpha$-glucosidase activity and postprandial hyperglycemia. Nutrition 2005; 21(6): 756-761.

21. Lindstad RI, Teigen K, Skjeldal L. Inhibition of sorbitol dehydrogenase by nucleosides and nucleotides. Biochemical and Biophysical Research Communications 2013; 435 (2):202-208. 
22. Bagewadi ZK, Muddapur UM, Madiwal SS, Mulla SI, Khan A. Biochemical and enzyme inhibitory attributes of methanolic leaf extract of Datura inoxia Mill. Environmental Sustainability 2019; 2(1): 75-87.

23. Mahmood N. A review of $\alpha$-amylase inhibitors on weight loss and glycemic control in pathological state such as obesity and diabetes. Comparative Clinical Pathology 2016; 25(6): 1253-1264.

24. Li K, Yao F, Xue Q, Fan H, Yang L, Li X, Sun L, Liu Y. Inhibitory effects against $\alpha$-glucosidase and $\alpha$-amylase of the flavonoids-rich extract from Scutellaria baicalensis shoots and interpretation of structure-activity relationship of its eight flavonoids by a refined assign-score method. Chemistry Central Journal 2018; 12(1): 82.doi: 10.1186/ s13065-018-0445-y

25. Aslan HE, Beydemir Ş. Phenolic compounds: the inhibition effect on polyol pathway enzymes. ChemicoBiological Interactions 2017; 266: 47-55.

26. Jang S-M, Kim M-J, Choi M-S, Kwon E-Y, Lee M-K. Inhibitory effects of ursolic acid on hepatic polyol pathway and glucose production in streptozotocin-induced diabetic mice. Metabolism 2010; 59(4):512-519.

27. Wang Z-h, Hsu C-c, Huang C-n, Yin M-c. Anti-glycative effects of oleanolic acid and ursolic acid in kidney of diabetic mice. European journal of pharmacology 2010; 628 (1-3): 255-260.

28. Kazeem MI, Ashafa AOT. Antioxidant and inhibitory properties of Dombeya burgessiae leaf extracts on enzymes linked to diabetes mellitus. Transactions of the Royal Society of South Africa 2016; 71(2): 167-174.

29. El-Kaissi S, Sherbeeni S. Pharmacological management of type 2 diabetes mellitus: an update. Current diabetes reviews 2011; 7(6): 392-405.

30. Sunmonu TO, Lewu FB. Phytochemical Analysis, in vitro Antioxidant Activity and Inhibition of Key Diabetic Enzymes by Selected Nigerian Medicinal Plants with Antidiabetic Potential. Indian Journal of Pharmaceutical Education and Research 2019; 53(2): 250-260.

31. Oboh G, Adebayo AA, Ademosun AO. Erectionstimulating, anti-diabetic and antioxidant properties of
Hunteria umbellata and Cylicodiscus gabunensis water extractable phytochemicals. Journal of Complementary and Integrative Medicine 2017; 15(1). https:// doi.org/10.1515/jcim-2016-0164

32. Association AD. Diagnosis and classification of diabetes mellitus. Diabetes care 2013; 36(Suppl 1):S67-S74.https:// doi.org/10.2337/dc13-S067 .

33. Reddy A, Ramana KV. Aldose reductase inhibition: emerging drug target for the treatment of cardiovascular complications. Recent patents on cardiovascular drug discovery 2010; 5(1): 25-32.

34. Aldred EM. Pharmacology: A Handbook for Complementary Healthcare Professionals: 1st ed. Elsevier; 2008. p. 352

35. You Q, Chen F, Wang X, Jiang Y, Lin S. Anti-diabetic activities of phenolic compounds in muscadine against alpha-glucosidase and pancreatic lipase. LWT-Food science and technology 2012; 46(1): 164-168.

36. Garud MS, Kulkarni YA. Gallic acid attenuates type I diabetic nephropathy in rats. Chemico-Biological Interactions 2018; 282: 69-76.

37. Samarghandian S, Azimi-Nezhad M, Farkhondeh T. Catechin treatment ameliorates Diabetes and its complications in streptozotocin-induced diabetic rats. Dose-Response 2017; 1-7.

38. Amalan V, Vijayakumar N, Indumathi D, Ramakrishnan D. Antidiabetic and antihyperlipidemic activity of pcoumaric acid in diabetic rats, role of pancreatic GLUT 2: In vivo approach. Biomedicine \& Pharmacotherapy 2018; 84: 230-236.

39. Qi M-Y, Wang X-T, Xu H-L, Yang Z-L, Cheng Y, Zhou B. Protective effect of ferulic acid on STZ-induced diabetic nephropathy in rats. Food \& Function. 2020,11, 37063718. https://doi.org/10.1039/C9FO02398D

40. Kamalakkannan N and Stanely Mainzen Prince P. Rutin improves the antioxidant status in streptozotocin-induced diabetic rat tissues. Molecular \& Cellular Biochemistry 2006; 293: 211-219. 